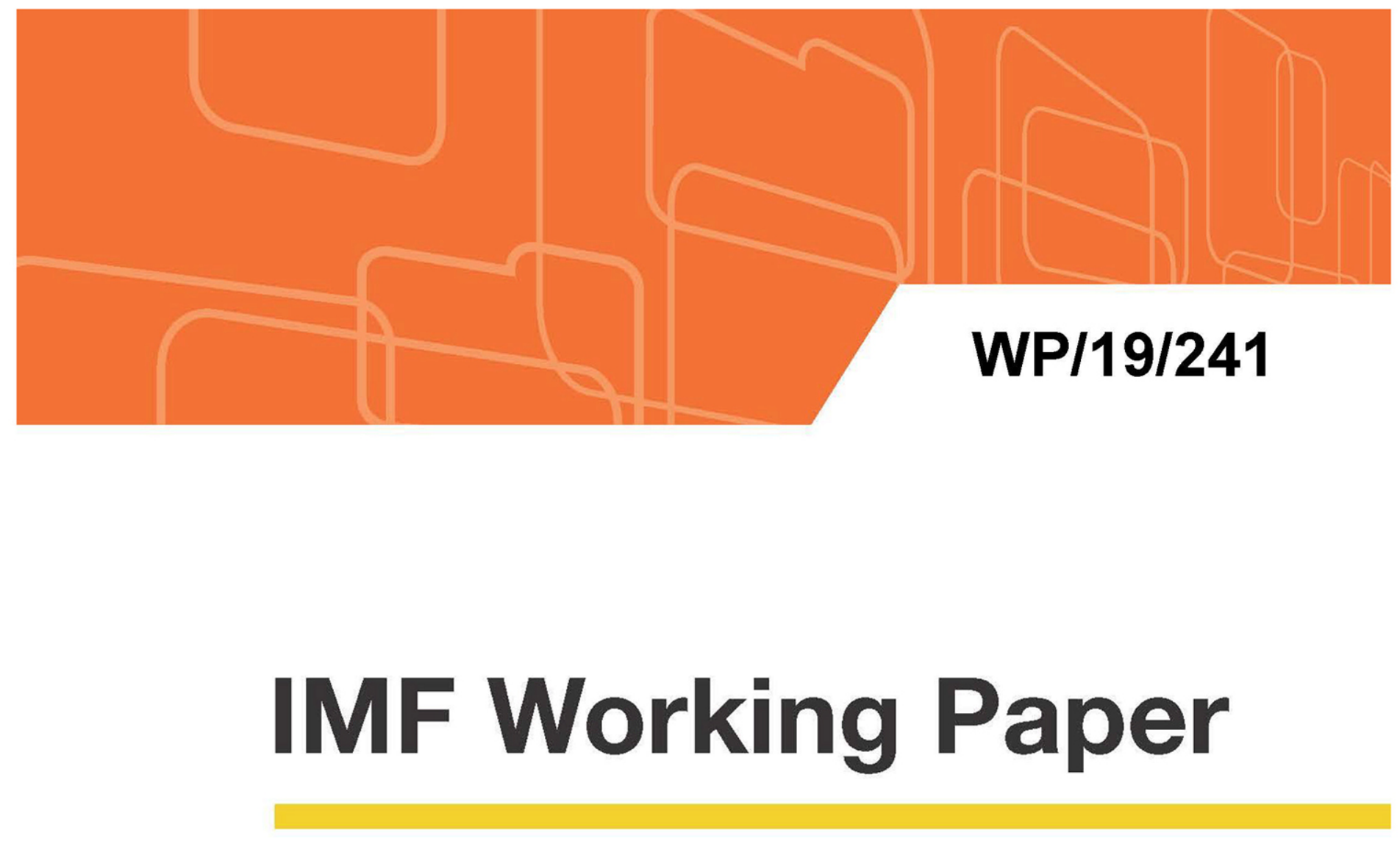

\title{
A Quantitative Analysis of Female Employment in Senegal
}

by Vivian Malta, Angelica Martínez Leyva, Marina M. Tavares

IMF Working Papers describe research in progress by the author(s) and are published to elicit comments and to encourage debate. The views expressed in IMF Working Papers are those of the author(s) and do not necessarily represent the views of the IMF, its Executive Board, or IMF management. 


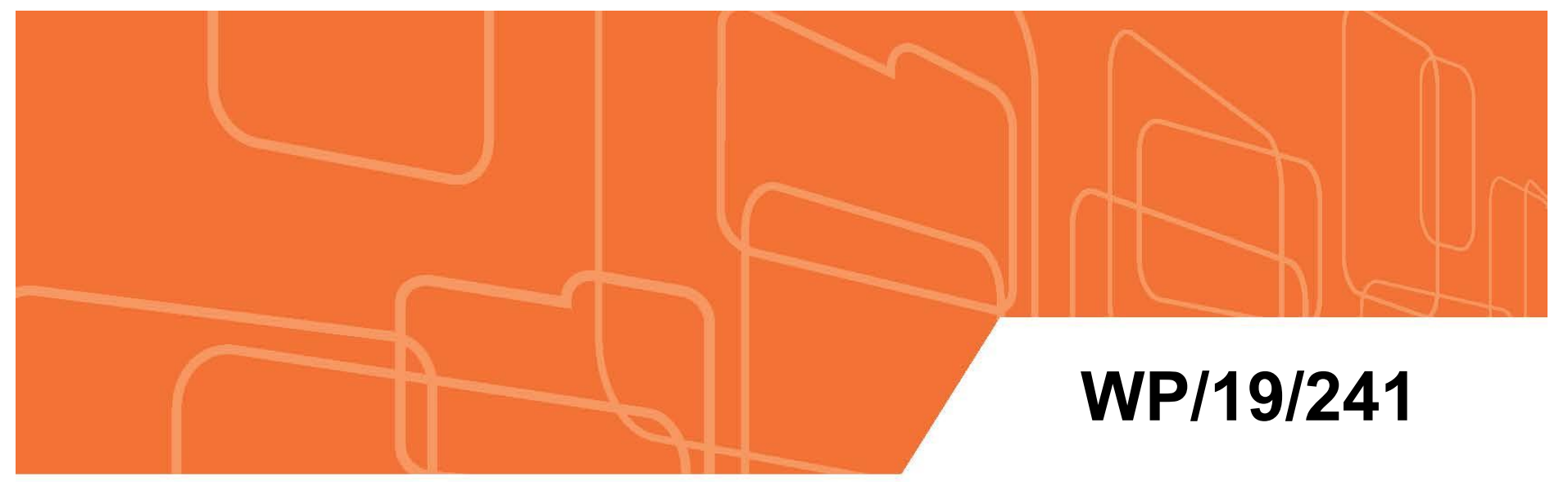

\section{IMF Working Paper}
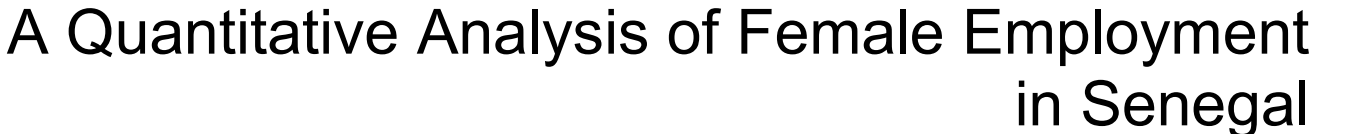

IMF Working Papers describe research in progress by the author(s) and are published to elicit comments and to encourage debate. The views expressed in IMF Working Papers are those of the author(s) and do not necessarily represent the views of the IMF, its Executive Board, or IMF management. 


\title{
IMF Working Paper
}

Strategy, Policy and Review Department

\section{A Quantitative Analysis of Female Employment in Senegal}

\section{Prepared by Vivian Malta, Angelica Martínez Leyva, and Marina M. Tavares ${ }^{1}$}

\author{
Authorized for distribution by Johannes Wiegand
}

November 2019

\begin{abstract}
IMF Working Papers describe research in progress by the author(s) and are published to elicit comments and to encourage debate. The views expressed in IMF Working Papers are those of the author(s) and do not necessarily represent the views of the IMF, its Executive Board, or IMF management.
\end{abstract}

\begin{abstract}
Female-to-male employment in Senegal increased by 14 percentage points between 2006 and 2011. During the same period years of education of the working age population increased 27 percent for females and 13 percent for males, reducing gender gaps in education. In this paper, we quantitatively investigate the impact of this increase in education on female employment in Senegal. To that end, we build an overlapping generations model that captures barriers that women face over their life-cycle. Our main findings are: (i) the improvement in years of education can explain up to 44 percent of the observed increased in female-to-male employment ratio and (ii) the rest can be explained by a decline in the discrimination against women in the labor market.
\end{abstract}

JEL Classification Numbers: E24, E62, H31, J16, J22, N37, O11

Keywords: Labor Force Participation, Development

Authors’ E-Mail Addresses: VMalta@imf.org, Angelica.Martinez-Leyva@warwick.ac.uk, MMendestavares@imf.org

\footnotetext{
${ }^{1}$ We are very grateful for Lisa Kolovich and Sandra Lizarazo's invaluable inputs. We also thank Stefania Fabrizio, Anna Fruttero, Federica Marzo, the IMF's Senegal team and participants of the 2019 CSAE Conference in Oxford for their comments. This paper is part of a research project on macroeconomic policy in low-income countries supported by the U.K. Department for International Development (DFID). The research results and conclusions expressed herein are those of the authors and do not necessarily reflect the views of DFID, the IMF, its Executive Board, or its Management.
} 


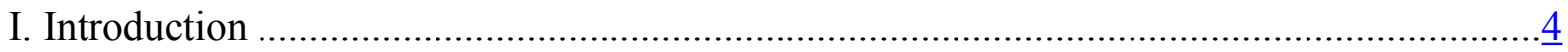

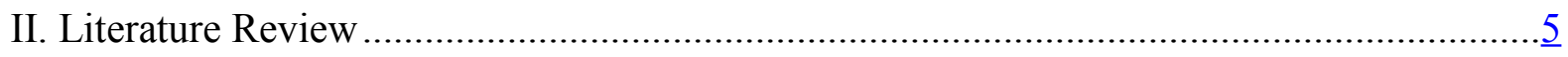

III. Background On Senegal ......................................................................................

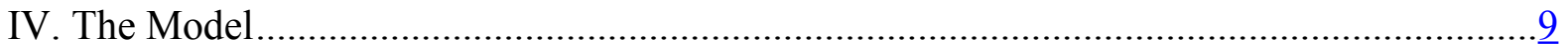

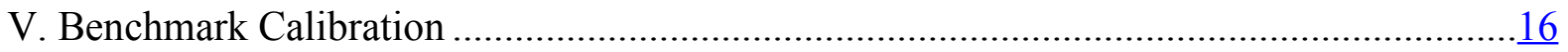

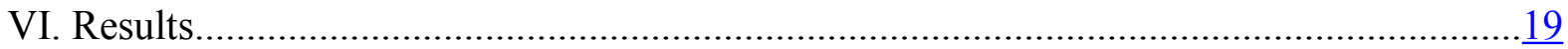

A. Simulating the Observed Increase in Years of Education of the Labor Force......... $\underline{20}$

B. Simulating the Reduction in Discrimination in the Labor Market.........................21

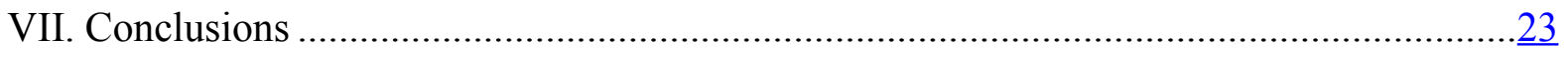

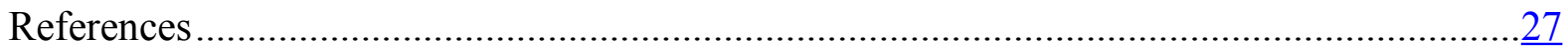

Tables

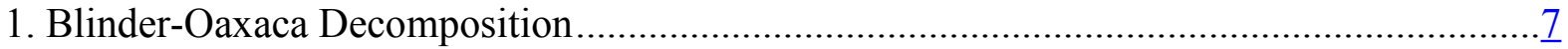

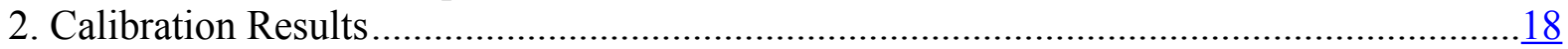

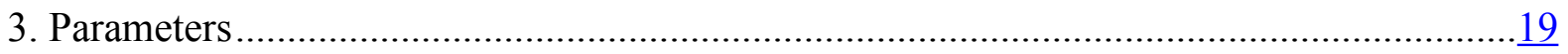

Figures

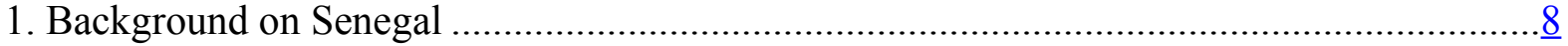

2. Results of the Education and Anti-Discriminatory Policies ..........................................25

3. Changes in Households' Per Capita Income, by Decile of Income Distribution..................26 


\section{INTRODUCTION}

The condition of Senegalese women has improved substantially in the last years. According to the International Labour Organization (ILO), female-to-male employment ratio in Senegal increased from 0.46 to 0.60 between 2006 and 2011, and women are getting more education. The average years of education of working age women grew 27 percent during the same period, helping reducing gender gaps in education in the country.

In this paper, we link these trends and quantify the impact of the rise in females' years of education on female-to-male employment. We develop a micro-founded overlapping generations model that allows us to analyze the consequences of changes in education on labor outcomes, on macroeconomic aggregates and on distributional variables. In our framework, women face different barriers to their development over the life-cycle, starting from the provision of less education to them, passing through the costs of taking care of the home and family and through discrimination in the labor market. The model developed is suited to run fiscal and gender-equality-related policy experiments, such as changes to the tax code, conditional cash transfer programs, government-funded education expenditure, female work regulation, childcare subsidies, family and social costs from female employment, and some gender-based anti-discrimination policies.

The model is calibrated to the Senegalese economy using both micro and macro data. This includes information such as: the size of formal and informal sectors relative to GDP; the proportion of labor force employed in the formal and informal sectors; the country's income distribution; effective tax rates; government expenditure on education; distribution of education across the population; female labor force participation (relative to male's); gender wage gaps in the formal and informal sectors; returns to education and work experience; and family consumption patterns.

Using this framework, we find that the increase in years of education of the working age population and the respective reduction of gender gaps in education that occurred between 2006 and 2011 can explain up to 44 percent of the growth in female-to-male employment ratio. The remaining 56 percent can potentially be explained by a reduction in gender discrimination in the labor market that would have meliorated females' earnings and productivity by 4.7 percentage points.

The economic rationale of those results is that higher levels of education, particularly women's education, and lower levels of discrimination in the labor market raise women's competitiveness and returns from working. This induces some women to enter the labor force and some men and women to shift from the informal to the formal sector. The resulting gains in productivity and in female income generate an economic boost that, in general equilibrium, affects positively male's earnings. The model predicts that the observed improvement in education levels contributed to both higher economic growth and lower income inequality, as households from lower income deciles gained relatively more from the education policy. Regarding the reduction in discrimination on the labor market, the model predicts large effects on female employment and on GDP, but those would have been more unevenly distributed across the population - in fact, they could have been slightly detrimental to some low-income families. 
The remaining of the paper is divided as follows: in the next section, we present a brief literature review, in section III we offer stylized facts on Senegal. In section IV the model is presented, section $\mathrm{V}$ contains the explanation of the calibration methodology, and section VI the main results. Section VII concludes the paper.

\section{LiteratURE REVIEW}

This paper contributes to the literature that studies the effects of education and labor market discrimination on female labor force participation. Theoretical underpinnings for the positive relationship between female education and labor force participation are provided by Mincer and Polachek (1974) and Becker (1985). Eckstein and Lifshitz (2011) show that improvements in education can explain about 33 percent of the observed increase in female employment in the United States from 1964 to 2007. Steinberg and Nakane (2012) estimate that a one standard deviation increase in the education level in OECD countries is associated with a 3-percentage point increase in female labor force participation. Bowen and Finegan (1966) find that the completion of an extra year of schooling was associated with an average increase of about three percentage points in the labor force participation rate of married women in the United States. In a cross-country empirical study from 1980 to 2014, Jain-Chandra and others (2018) find that public education expenditure is positively associated with smaller gender gaps in labor force participation. Ganguli, Hausmann, and Viarengo (2014) note while gender gaps in education have been largely closed or reversed in favor of women in some nations, there is much heterogeneity across countries regarding whether female labor force participation rates increased as well.

Our paper is also related to an extensive literature that studies the impact of government policy on female labor force participation. For example, governments, by encouraging or funding parental leave, childcare subsidies, and/or flexible work arrangements can help boost rates of female labor force participation (Jacobsen 1998; Kalb 2018; IMF 2017a; IMF 2017b). Cash transfers can be targeted towards training, female education enrollment, and health care, which can lead to increases in female labor force participation (IMF 2016). Investing in infrastructure, such as safer transportation alternatives, improved sanitation facilities and access to water can reduce the unpaid time burdens women face and allow for higher levels of female labor force participation (IMF 2017c; IMF 2017d; Jain-Chandra and others, 2018). Tax policies can also directly impact a household's and/or a woman's decision to enter the formal labor force (see for instance Grown and Valodia, 2010; LaLumia, 2017; IMF 2017e).

This paper is also related to a growing macro literature that studies the impact of government policy on female labor force participation in a micro-founded framework featuring life-cycle dynamics and agents' heterogeneity, such as Chade and Ventura (2002) and Guner, Kaygusuz, and Ventura (2011). While this literature has focused in the United States and advanced economies, our paper is the first to focus on low income countries. In this respect, our work is related Peralta and others (2019), that studies the distributional impact of tax reforms in low income countries, though it does not distinguish males from females. 


\section{BACKGROUND ON SENEGAL}

The share of female labor force in total labor force has been increasing over the past two decades at a faster pace in Senegal than in the rest of sub-Saharan Africa (Figure 1a). The growth was particularly notable between 2006 to 2011, when women's share in the total labor force participation rate jumped from 35 percent to 38 percent, and the female-to-male employment increased by 14 percentage points (Figure 1b). Despite this progress, female labor force participation in Senegal remains below sub-Saharan Africa's average.

Gender gaps in primary education in both enrollment and completion rates have closed and even reversed in Senegal. According to UNESCO, primary education completion rates rose from 33 percent for girls and 43 percent for boys in the year of 2000 to 64 percent and 54 percent, respectively, in 2016. However, gender gaps in secondary and tertiary education persist, with girls' completion rates in secondary education and enrollment rates in tertiary education lower than boys' rates. The Demographic and Health Survey (DHS) for that country reported that, in 2012, the average female completion rate for secondary education was only 13 percent, compared to 21 percent for boys.

Using 2005 DHS and 2011 DHS to compare education attainment for different age groups (in working age), we find that the young men and women were the most benefited from the rise in education levels. For instance, the share of females from 15 to 19 years of age with some secondary education jumped from 18 percent to 35 percent (while for males in the same age group it changed from 24 to 43 percent). For young women between 20 and 24 years of age, the percentage with some secondary education increased from 12 to 19 percent (while for males in the same age group it has risen from 21 to 29 percent). The survey also allows us to make estimations of the total increase in education of the working age population by level of income, and we find that the largest improvements in terms of percentage changes were in the bottom 60 percent of the income distribution (Figure 1e), which had the lowest education attainment.

Senegal's progress in education in the 2000s, in particular youth education, was probably helped by the government's higher spending on education and its new education program. Government spending on education as a share of GDP roughly doubled from 3.2 percent in 2000 to 6.1 percent in 2011 (Figure 1c). In 2000, Senegal's government launched the Ten-Year Education and Training Program (PDEF).

The first phase of the PDEF program focused on primary and lower secondary enrollment, and one of its objectives was to increase education of girls and boys living in disadvantaged regions. In addition, the first phase also sought to modernize and strengthen the education sector management by improving the capacity of the Ministry of Education to set policies and guidelines. According to the World Bank (2006), the first stage was moderately successful. For instance, Senegal was able to sustain an increase in terms of access to education through the construction of schools and recruiting teachers. The schools' construction was achieved thanks in large part to a significant effort in classroom construction at the primary level. During this first phase, according to the Word Bank, the number of public primary schools increased from 4,338 schools in 2000 to 5,795 schools in 2005 , leading to a decline in the number of pupils-to-teacher ratio (Figure 1d). 
The second phase of the program focused on three aspects. The first aspect centered on expanding access in middle schools, improving retention in elementary and middle schools, and constructing latrines and clean water access points, which is extremely valuable to girls. Second, the program aimed to improve the quality of classroom instruction by providing textbooks and pedagogic inputs to schools, training teaches and directors, and improving the evaluation system. The last component concentrated on building a solid data collection mechanism and the capacity needed to use the results for policy development. According to the World Bank (2012a), the second phase was also moderately satisfactory. Some of the indicators measuring progress towards achievement showed significant progress or had been met. In terms of quality, the school projects as well as the regional training and quality improvement plans showed a satisfactory improvement.

In addition to the PDEF plan, USAID helped Senegal improve both the access to and the quality of education. ${ }^{2}$ In 2003 for example, a USAID program sought to improve access, quality, and governance in middle schools. As a result, in USAID-assisted regions, the rates for both middle school enrollment and the number of girls attending middle school have increased.

Despite the progress in education, women still face a large gender pay gap in Senegal. Using micro data from Senegal's 2011 Household Survey, we estimate how much of the overall gap is attributable to differences in observable versus unobservable characteristics. We use the Blinder-Oaxaca decomposition to estimate the explained (observable) and unexplained (unobservable) components of the gender wage gap. The observable characteristics that we control for are region, ethnic group, religion, years of education, age, work experience (measured by how many years working in main job), informality, occupation, and sector. Table 1 shows that the OLS estimation points to a total gender wage gap of 47 percent, and that only a third of this wage gap can be explained by the control variables. The remaining two thirds of the wage gap cannot be attributable to differences in education, experience, etc. This unexplained portion of the wage gap can reflect unobserved variables but also gender discrimination in the labor market - a wage premium for male workers that cannot be explained by observable individual and job characteristics.

Table 1. Blinder-Oaxaca Decomposition

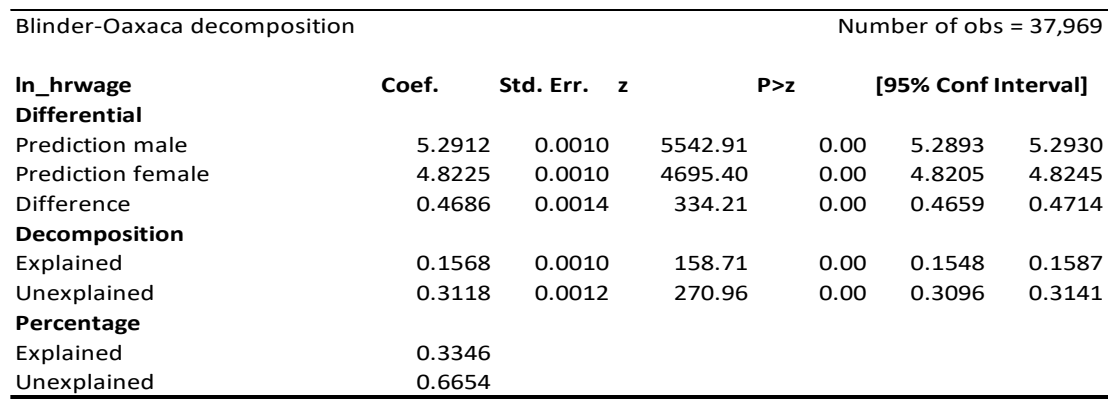

\footnotetext{
${ }^{2}$ Source: USAID - Improving education Senegal
} 
Figure 1. Background on Senegal

(a)

Labor force, female

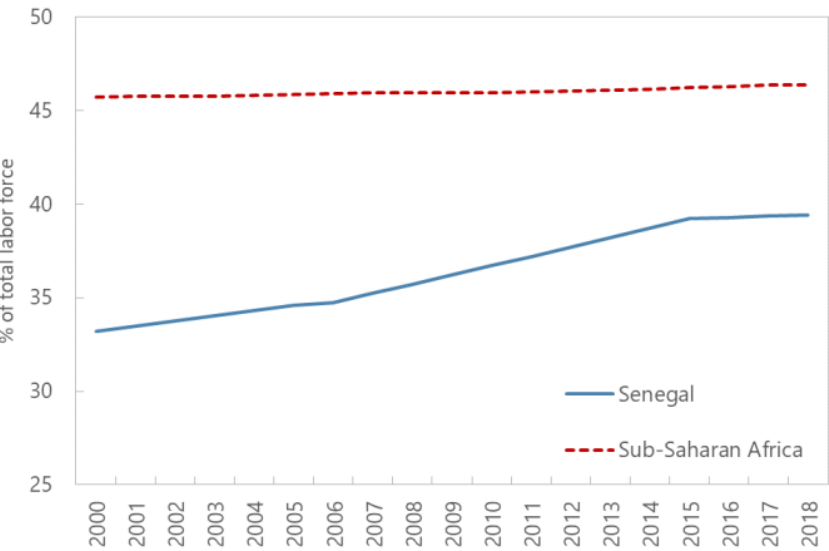

Source: ILO estimated accessed at World Bank data website

(c)

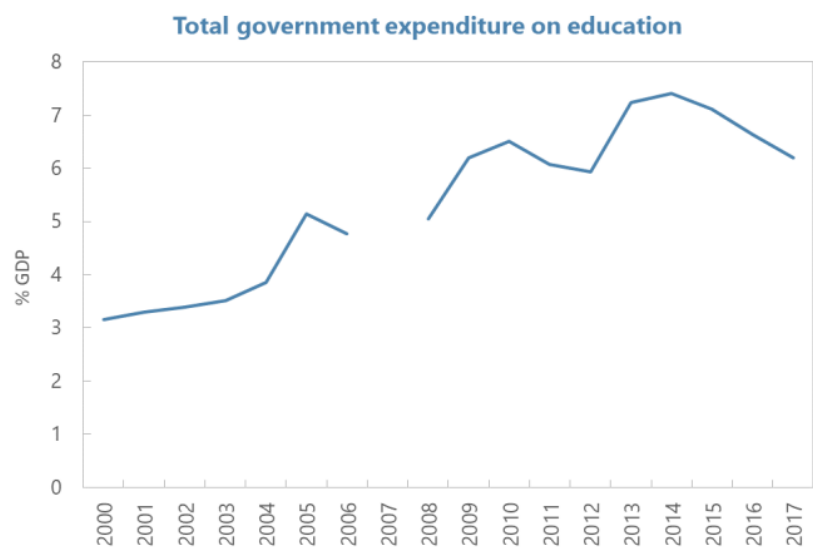

(e)

Percentage Increase in years of education of working age population from 2005 to 2011 ,

per ventile of income distribution

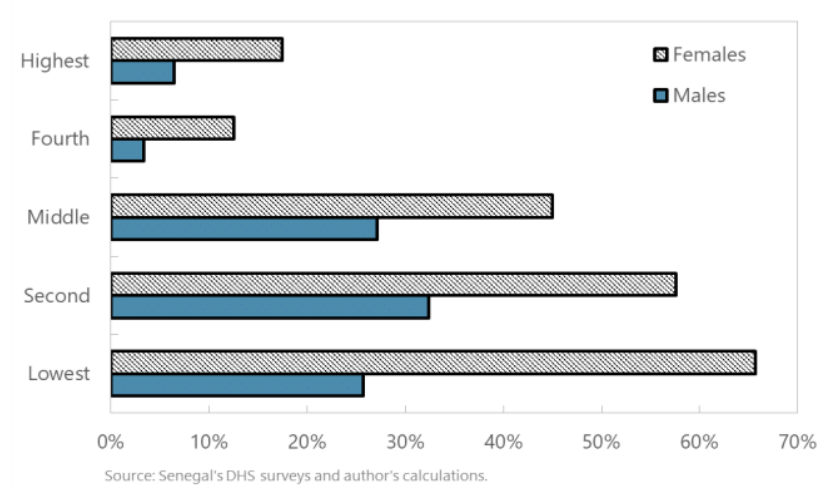

(b)

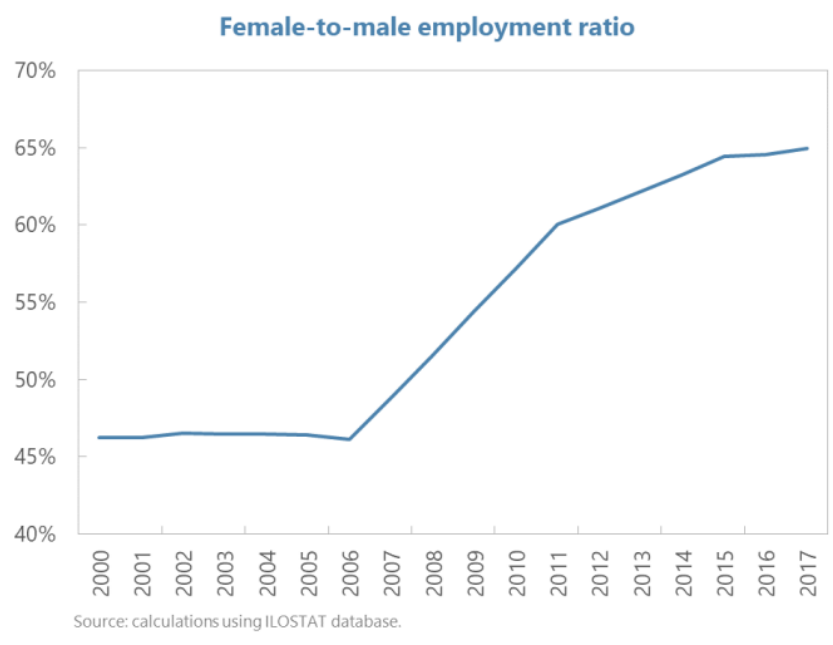

(d)

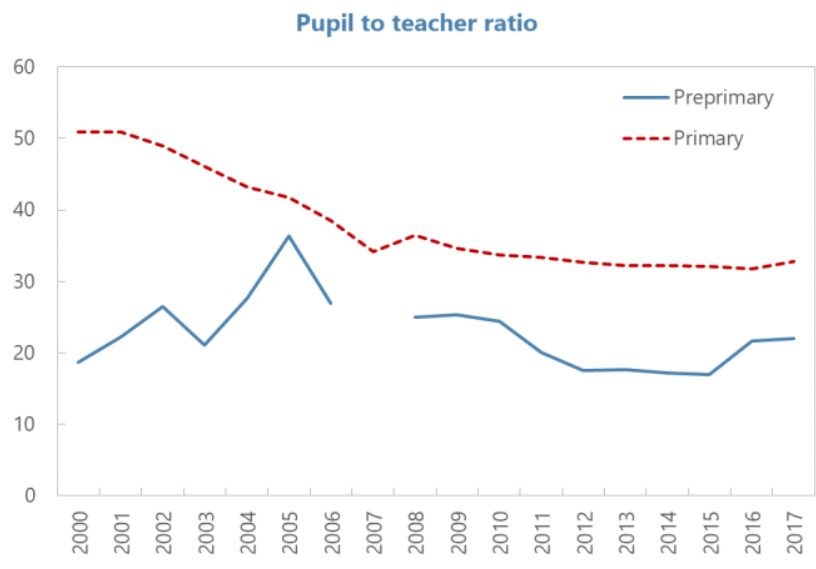

Source: World Bank indicators, extracted from UNESCO

(f)

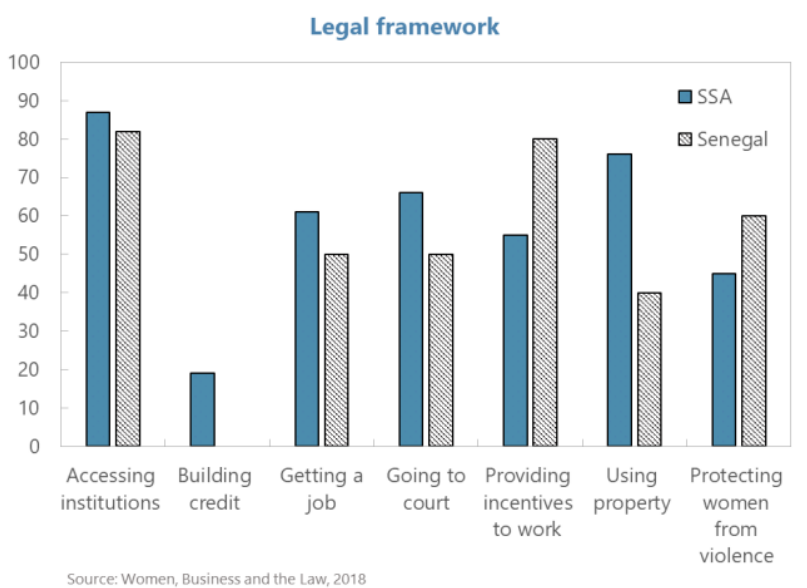


Although we cannot provide an exhaustive empirical explanation for the large unexplained wage gap, according to World Bank (2018) women in Senegal still face gender-based discriminatory legal restrictions that prevent non-pregnant, non-nursing women from performing the same job as men (Figure 1f). ${ }^{3}$ Furthermore, there are no laws in Senegal mandating equal remuneration for work of equal value nor laws censuring discrimination based on gender in hiring, in job's promotions or in dismissal. ${ }^{4}$ Moreover, discrimination in access to finance based on gender or marital status is not prohibited by law and the constitution does not formally recognize, nor does it prohibit discrimination against women that may result from customary laws.

Using the model described in the next section, we quantify the importance of the increase of years of education of the working age population on the surge in female-to-male employment and labor force participation noted in the 2006-2011 period. We also use the model to quantify the consequences of a possible reduction in gender discrimination in the formal and informal labor markets.

\section{THE MODEL}

We construct an overlapping generations (OLG) model in which heterogenous agents live in a small open economy for three periods and die at the end of the third period. Each generation consists in a continuum of agents. Individuals initially differ from each other by generation, gender, initial endowment and access to the savings market. Individuals with higher initial endownments can save and borrow at an exogenous interest rate $\mathrm{r}^{*}$, while poor individuals are hand-to-mouth. In this economy, in the first period, a household is comprised by a man and a women - husband and wife - and two children. In periods 2 and 3, the children have left to form their own households, and the original household is comprised only by the husband and the wife. Since all agents die at the end of period 3 and each couple has two children thoughout life, the population remains constant over time. ${ }^{5}$

Husband and wife make all the decisions together, including labor supply, consumption and savings/borrowing (richer households only). In terms of labor choices, they decide husband's labor supply in the formal and/or informal sector and women's female labor force participation and, in the case of participation, how much time she is going to work in the formal and informal sectors. There is no unemployment in the model, so that all individuals participating in the labor force are employed. In terms of consumption choices, they decide how much to consume of each of the two types of goods in the economy - formal and informal goods.

\footnotetext{
${ }^{3}$ Source: World Bank’s “Women, Business, and the Law”, 2018

${ }^{4}$ According to Marzo \& Atuesta (forthcoming), sexual harassment is not recognized as a criminal offense and 18 percent of working Senegalese women declared that they were asked to have sexual relations to get a promotion while 16 percent claimed they were refused a work contract for having rejected sexual advances

${ }^{5}$ In the calibration section we explain how we adjust the two-children assumption to account for higher fertility rates.
} 
Education for children and adolescent is provided by the government, and the amount of education is not equal across gender and initial endownments, to account for the heterogeneities seen in the data. Richer households can choose how much to save or borrow in each period and do not work in period 3 - during which they only spend their life-time savings. Whenever women supply labor there is a utility cost incurred by the family. This cost relates to the difficulty in coordinating multiple household activities, such as home production, child/elderly care, and other unpaid work. For some countries, this cost can also be interpreted as social and cultural barriers for a woman and her family when she works outside the home.

Production in the formal sector uses capital and labor, while the informal sector uses only labor. The formal sector in this economy is modeled as a representative firm that hires both male and female effective hours of labor and rent capital at rate $r^{*}$ from the rich households or from abroad, to produce the formal good. Besides being produced domestically, formal goods can be importated from abroad. Formal goods can be used as consumption goods, capital, or education.

Women suffer discrimination in the workplace when working in both the formal and informal sectors, and this is captured by parameters $\phi_{\text {fo }}$ and $\phi_{\text {inf }}$ multipliying the production functions. This discrimination constrains women from achieving their full salary, productivity, and career potential.

The government collects taxes on labor income, on consumption, and on firms' revenues and spends on education, formal goods and cash transfers. The government has access to external financial markets and can finance its debt by borrowing at interest rate $\mathrm{r}^{*}$ from abroad or from domestic households with access to the financial sector.

\section{Preferences}

Households maximize utility over the three periods of life and discount the future at rate $\beta$. We assume that, for each period $\mathrm{t}$, households have log-linear preferences over consumption of formal goods $\left(c_{t}^{f o}(\varepsilon)\right)$ and informal goods $\left(c_{t}^{\text {inf }}(\varepsilon)\right)$, and disutility over total female labor supply $\left(\mathrm{l}_{t}^{f}(\varepsilon)\right)$ :

$$
u\left(\mathrm{c}_{t}(\varepsilon), \mathrm{l}_{t}^{f}(\varepsilon),\right)=\xi_{f o} \log \left(\mathrm{c}_{t}^{f o}(\varepsilon)\right)+\xi_{\text {inf }} \log \left(\mathrm{c}_{t}^{\text {inf }}(\varepsilon)\right)-\xi_{l}(\varepsilon) I\left(\mathrm{l}_{t}^{f}>0\right),
$$

where $\varepsilon$ is the initial endowment; $c_{t}(\varepsilon)=\left\{c_{t}^{f o}(\varepsilon), c_{t}^{\text {inf }}(\varepsilon)\right\}$ is a vector composed by formal and informal consumption; $\xi_{\text {fo }}$ and $\xi_{\text {inf }}$ are parameters reflecting the preference over, respectively, formal and informal goods consumption; and $\xi_{l}(\varepsilon)$ is a parameter describing the utility cost for families when women participate in the labor market. Moreover, female labor force is the sum of the amount worked in the formal and informal sectors $l_{t}^{f}(\varepsilon)=l_{t}^{f, f o}(\varepsilon)+$ $l_{t}^{f, i n f}(\varepsilon)$. 


\section{Human Capital}

Each family is born with initial endownment $\varepsilon \sim \operatorname{lognormal}\left(0, \sigma^{2}\right)$, which is assumed to be passed deterministically throughout generations. Human capital is a function of this initial endownment and evolves according to the accumulation of education and labor experience.

Thus, in period 1 of the household's life, human capital of the husband and wife are given by

$$
h_{1}=\varepsilon\left(e^{i}(\varepsilon)\right)^{\alpha_{e}} \text {, where gender } i \in\{\mathrm{f}, \mathrm{m}\},
$$

where education of the husband or the wife $e^{i}(\varepsilon)$ depends on the gender $i$ and initial endowment $\varepsilon$. In periods 2 and 3 of the household, human capital accumulation for the husband and the wife are given by

$$
h_{t}^{i}=\left\{\begin{array}{ll}
\left(1+g_{t}^{i}\right) h_{t-1}^{i}, & \text { if } l_{t-1}^{i}>0 \\
h_{t-1}^{i}, & \text { if } l_{t-1}^{i}=0
\end{array}, \text { where gender } i \in\{\mathrm{f}, \mathrm{m}\} \text { and period } \mathrm{t} \in\{2,3\} .\right.
$$

The definition above means that if the individual doesn't work in one period, then his/her human capital remains the same in the next period, while if he/she works, human capital grows at a rate $g_{t}^{i}$ for the next period. The notation $g_{t}^{i}$ implies women and men can have different returns to experience, which is one source of gender gap in the labor market.

\section{Technologies}

Formal Markets - Formal goods are produced by a representative firm using effective labor supplied by individuals and capital in a Cobb-Douglas production function. The formal goods production function is given by:

$$
Y^{f o}=\mathrm{K}^{\alpha_{f o}}\left(L^{m, f o}+\phi_{f o} L^{f, f o}\right)^{1-\alpha_{f o}},
$$

where $L^{m, f o}$ is the total effective male labor hired; $L^{f, f o}$ is the total effective female labor hired; $\phi_{f o}$ is the parameter capturing the discrimination against women that reduces their labor efficiency and wages; $\alpha_{f o}$ is the factor share; and $\mathrm{K}$ is the stock of capital used in the formal goods production.

Informal Markets - The production of informal goods is made by households and is given by:

$$
\begin{gathered}
y_{t}^{m, i n f}=\left[l_{t}^{m, i n f} h_{t}^{m}\right]^{1-\alpha_{\text {inf }}} \\
y_{t}^{f, \text { inf }}=\phi_{\text {inf }}\left[l_{t}^{f, \text { inf }} h_{t}^{f}\right]^{1-\alpha_{\text {inf }}},
\end{gathered}
$$

respectively for males and females, where $\alpha_{i n f}$ is a parameter defining the concavity of the

production function, $l_{t}^{i, \text { inf }} h_{t}^{i}$ (where gender $i \in\{\mathrm{f}, \mathrm{m}\}$ ) is the total effective labor hours 
supplied, and $\phi_{\text {inf }}$ is the parameter capturing the discrimination against women that reduces their labor efficiency and earnings in the informal sector.

\section{Optimization Problems}

Let $p_{\text {inf }}$ be the price of the informal good, while the formal good's price is the numeraire. For notation simplicity, define $x_{t}(\varepsilon)=\left\{c_{t}^{f o}(\varepsilon), c_{t}^{\text {inf }}(\varepsilon), l_{t}^{f, f o}(\varepsilon), l_{t}^{f, \text { inf }}(\varepsilon), l_{t}^{\text {m, fo }}(\varepsilon), l_{t}^{\text {m,inf }}(\varepsilon)\right\}$ a vector of consumtion and labor choices of a hand-to-mounth household with initial endownment $\varepsilon$.

Households Problem -A hand-to-mouth household maximizes life-time utility subject to the budget constraints:

$$
\begin{gathered}
\max _{\left\{x_{1}(\varepsilon), x_{2}(\varepsilon), x_{3}(\varepsilon)\right\}} u\left(c_{1}(\varepsilon), \mathrm{l}_{1}^{f}(\varepsilon)\right)+\beta u\left(c_{2}(\varepsilon), \mathrm{l}_{2}^{f}(\varepsilon)\right)+\beta^{2} u\left(c_{3}(\varepsilon), \mathrm{l}_{3}^{f}(\varepsilon)\right) \\
\text { subjected to } \\
\theta_{t}\left[\left(1+\tau_{t}^{c}\right) c_{t}^{f o}(\varepsilon)+p_{\text {inf }} c_{t}^{\text {inf }}(\varepsilon)\right] \leq B_{t}(\varepsilon) \quad \mathrm{t} \in\{1,2,3\},
\end{gathered}
$$

where budget $B_{t}(\varepsilon)$ is given by:

$$
\begin{aligned}
& B_{t}(\varepsilon) \\
& = \begin{cases}\left(1-\tau^{f}\right) w^{f} l_{t}^{f, f o}(\varepsilon) h_{t}^{f}(\varepsilon)+\left(1-\tau^{m}\right) w^{m} l_{t}^{m, f o}(\varepsilon) h_{t}^{m}(\varepsilon)+p_{\text {inf }}\left(y^{m, i n f}(\varepsilon)+y^{f, \text { inf }}(\varepsilon)\right)+o_{t}(\varepsilon), & \text { if } l_{t}^{f}(\varepsilon)>0 \\
\left(1-\tau^{m}\right)\left(w^{m} l_{t}^{m, f o}(\varepsilon) h_{t}^{m}(\varepsilon)\right)+p_{\text {inf }} y^{m, i n f}(\varepsilon)+o_{t}(\varepsilon), & \text { if } l_{t}^{f}(\varepsilon)=0\end{cases}
\end{aligned}
$$

and

$$
\begin{gathered}
l_{t}^{f}(\varepsilon)=l_{t}^{f, f o}(\varepsilon)+l_{t}^{f, \text { inf }}(\varepsilon) \\
y_{t}^{m, i n f}(\varepsilon)=\left[l_{t}^{m, \text { inf }}(\varepsilon) h_{t}^{m}(\varepsilon)\right]^{1-\alpha_{\text {inf }}} \\
y_{t}^{f, \text { inf }}(\varepsilon)=\phi_{\text {inf }}\left[l_{t}^{f, \text { inf }}(\varepsilon) h_{t}^{f}(\varepsilon)\right]^{1-\alpha_{\text {inf }}} \\
\theta_{t}= \begin{cases}\theta, & \text { if } \mathrm{t}=1 \\
1, & \text { otherwise, }\end{cases}
\end{gathered}
$$

and where $\theta>1$ captures the extra consumption cost from having children in the house in period $1 ; \tau_{t}^{c}$ is the tax rate on formal goods; $\tau^{f}$ and $\tau^{m}$ are the effective labor income tax rate for females and males, respectively; $w^{f}$ and $w^{m}$ are formal sector wages per effective unit of time for females and males, respectively; and $o_{t}(\varepsilon)$ is a cash transfer from the government to households.

Households with access to financial markets (richer households) face a similar maximization problem, so we restrain from exposing here. The only differences compared to hand-to-mouth households are: (i) they choose how much to save or borrow in periods 1 and 2 in order to 
smooth their lifetime income and; (ii) they do not work in period 3, when they use their savings to consume.

Firms problem - A representative firm in the formal sector hires both male and female effective hours of labor, $L^{m, f o}$ and $L^{f, f o}$, and capital $K$ (that depreciates at rate $\delta$ ) to produce the formal good. The firm's profit maximization problem is given by:

$$
\max _{\left\{L^{f, f o}, L^{m, f o}, K\right\}}\left(1-\tau^{v}\right) \mathrm{K}^{\alpha_{f o}}\left(L^{m, f o}+\phi_{f o} L^{f, f o}\right)^{1-\alpha_{f o}}-\left(w^{m} L^{m, f o}+w^{f} L^{f, f o}\right)-\left(r^{*}+\delta\right) K
$$

\section{Government Budget Constraint}

The government taxes consumption at rate $\tau^{c}$, female (formal) labor income at rate $\tau^{f}$, male (formal) labor income at rate $\tau^{m}$, and firms' revenues at rate $\tau^{v}$. Thus, government revenues from consumption taxes sum

$$
R_{t}^{c}=\tau^{c} \mu \int_{\varepsilon}\left[\theta c_{1}^{f o}(\varepsilon)+c_{2}^{f o}(\varepsilon)+c_{3}^{f o}(\varepsilon)\right] d \varepsilon,
$$

where $\mu$ indicates the equal measure of each generation over the entire population. Government revenues from labor income (wages) sum

$$
R_{t}^{w}=\mu \sum_{j=1}^{3} \tau^{m} \int_{\varepsilon} w^{m} l_{j}^{m, f o}(\varepsilon) h_{j}^{m}(\varepsilon) d \varepsilon+\tau^{f} \int_{\varepsilon} w^{f} l_{j}^{f, f o}(\varepsilon) h_{j}^{f}(\varepsilon) d \varepsilon,
$$

where $\mathrm{j}$ indicates the generation. Finally, government revenues from corporate taxes sum

$$
R^{v}=\tau^{v} \mathrm{~K}^{\alpha_{f o}}\left(L^{m, f o}+\phi_{f o} L^{f, f o}\right)^{1-\alpha_{f o}} .
$$

At any period $t$, the government spends its revenues on formal goods (total expenditure on formal good equals to $G_{t}$ ), on education $\left(E_{t}\right)$, and on government transfers $O_{t}$. The government has access to external financial markets and can borrow externally or domestically (from richer households) to satisfy its expenditure, accumulating debt D. The government must satisfy its budget constraint at every period:

$$
D_{t+1}=\left(1+r^{*}\right) D_{t}+E_{t}+G_{t}+O_{t}-R_{t}^{c}-R_{t}^{w}-R_{t}^{v}
$$

where $O_{t}=\int_{\varepsilon} o_{t}(\varepsilon)$ and education spending is given by

$$
E_{t}=\mu \omega \int_{\varepsilon}\left(e^{f}(\varepsilon)+e^{m}(\varepsilon)\right) d \varepsilon
$$

and $\omega$ is a calibrated parameter that measures government expenditure (in price of formal goods) per year of education.

\section{Stationary Equilibrium}

A stationary equilibrium in this economy is characterized by a vector of allocations for each type of household from generation $\mathrm{j}$ and initial endowment $\varepsilon$ $\left\{c_{j}^{f o}(\varepsilon), c_{j}^{i n f}(\varepsilon), l_{j}^{f, f o}(\varepsilon), l_{j}^{f, \text { inf }}(\varepsilon), l_{j}^{m, f o}(\varepsilon), l_{j}^{m, \text { inf }}(\varepsilon), s_{j}(\varepsilon)\right\}_{j=1}^{3}$, a vector of firms' allocations $\left\{L^{f, f o}, L^{m, f o}, K\right\}$, a vector of government policies $\left\{\tau^{m}, \tau^{f}, \tau^{c}, \tau^{v}, o(\varepsilon), e^{m}(\varepsilon), e^{f}(\varepsilon), G\right\}$, and prices $\left\{w^{f}, w^{m}, p^{i n f}, r^{*}\right\}$, such that: 
i) Households solve their optimization problems;

ii) Firms maximize profits;

iii) Informal goods market clears:

$$
\begin{gathered}
C^{\text {inf }}=Y^{\text {inf }}, \text { where } \\
C^{\text {inf }}=\mu \int_{\varepsilon}\left[\theta c_{1}^{\text {inf }}(\varepsilon)+c_{2}^{\text {inf }}(\varepsilon)+c_{3}^{\text {inf }}(\varepsilon)\right] d \varepsilon \\
Y^{\text {inf }}=\mu \sum_{t=1}^{3} \int_{\varepsilon}\left[y^{f, \text { inf }}(\varepsilon)+y^{\text {minf }}(\varepsilon)\right] d \varepsilon ;
\end{gathered}
$$

iv) Formal labor market clears:

$$
L^{m, f o}=\mu \sum_{t \in\{1,2,3\}} \int_{\varepsilon} h_{t}^{m} l^{m, f o} d \varepsilon \quad \text { and } \quad L^{f, f o}=\mu \sum_{t \in\{1,2,3\}} \int_{\varepsilon} h_{t}^{f} l^{f, f o} d \varepsilon ;
$$

v) Government budget constraint is satisfied with debt stabilization; and

vi) Current account is always zero: $Y^{f o}-C^{f o}-\delta K-E-G=r^{*}(D+K-S)$

where $C^{f o}=\mu \int_{\varepsilon}\left[\theta c_{1}^{f o}(\varepsilon)+c_{2}^{f o}(\varepsilon)+c_{3}^{f o}(\varepsilon)\right] d \varepsilon$.

\section{Sources of Gender Inequality in the Model}

The main sources for gender inequality in the model are (i) the utility $\operatorname{cost} \xi_{l}(\varepsilon)$ that a family incurs when the wife works; (ii) the difference in the education provided by the government depending on endownment $\varepsilon$ and gender; (iii) the different returns to labor experience and; (iv) the remaining sources of discrimination faced by women in the formal and informal labor market, represented by $\phi_{f o}$ and $\phi_{\text {inf }}$.

The disutility incurred by the family when a woman supplies labor relates to the difficulty in coordinating multiple household activities, such as home production and child/elderly care, whenever the wife works outside, as well as social and cultural preferences of having women staying at home.

Parameters $\phi_{f o}$ and $\phi_{\text {inf }}$ in formal and informal production functions relate, respectively, to the residual discrimination women face in the labor market, either in the form of lower earnings per hour or in the form of less productivity due to the difficulty in navigating in the labor market and not realizing their full potential. These parameters are calibrated endogenously to match female-to-male earnings ratio in the formal and informal sectors - thus, they are residual differences in males' and females' production functions after taking into account discrepancies in education endownments, in returns to labor experience, and in the gender-based utility cost in the utility function. Discrimination in the workplace diminishes the potential for returns on 
women's employment, so that, even if they have the same experience and education (i.e. they have accumulated the same human capital as men), they earn less. Here we label discrimination in the labor market as any form of different treatment towards women and men that are not based on their endownments such as skills, education and experience. In the Results section, the second simulation is a hypothetical change in parameters $\phi_{f o}$ and $\phi_{\text {inf }}$ that could explain the part of the observed increase in female labor force participation not explained by improvements in education for girls in Senegal.

The hypothesis that parameters $\phi_{f o}$ and $\phi_{\text {inf }}$ directly reduce women's productivity and wages is well documented in the literature. The literature points to many reasons why women's productivity can be smaller than men's, given the same initial characteristics, such as education and occupation. As pointed by Becker (1985) and Albanesis \& Olivietti (2009), when women carry most of the responsibility in taking care of children and the house, they may spend less effort at work. Also, many studies (e.g., Blau and DeVaro 2007; Cobb-Clark 2001) find that women are less likely to be promoted, all else equal. Another reason for lower productivity is a reluctance of discriminatory customers or clients to buy goods or services provided by women. This makes women less productive in terms of a firm's revenue, thus depressing women's relative wages. For instance, Azmat and Ferrer (2015) find that female lawyers are less productive than male lawyers owing to discrimination: if corporate clients only want male lawyers, billable hours and number of new clients (their measures of productivity) will reflect this discrimination against women. Productivity differences between female-owned and maleowned businesses are often explained by differences in access to and use of productive resources. According to World Bank (2012b), among African firms in urban areas, the median female-owned firm in the formal sector has 2.5 times less start-up capital than the median maleowned firm, but it has 5 times more start-up capital than the median female-owned firm in the informal sector. The publication also shows differences in males and females' productivity in rural areas for many countries. Kilic et al (2014) shows that female-managed plots in Malawi are on average 25 percent less productive, and a large part of the differential comes from difficulty women face when trying to hire male workers.

In many countries, especially in sub-Saharan Africa, Middle East and North Africa, women's productivity is further constrined by the legal framework. World Bank's "Women, Business and the Law" publications show that women have difficulty in accessing institutions the same way as men, impairing their legal ability to make their own choices and to transform these choices into economic outcomes. The publication points to dozens of countries where the legal framework does not prohibit gender discriminatory practicies, preventing women from interacting with public authorities and the private sector the same way as men, and thus limiting their agency and economic activities. Examples include: women needing their husbands' permission to sign a contract or to get a job and women not having the same rights as men to open a bank account, to register a business, to be the head of the household, or to own, administer, or inherit property. In Senegal, our benchmark economy, the overall legal framework for women (as calculated by the publication's index) is below the sub-Saharan Africa average. For instance, in Senegal, there are still legal restrictions that prevent nonpregnant, non-nursing women from performing the same job as men. Furthermore, women's asset ownership is low and is not protected by law, as the Senegalese Family Code gives husbands the power to make all the decisions for the household. The system of inheritance 
described in the Family Code also gives advantages to men, hampering women's ability to have their own land or own equipment, thus reducing their ability to produce.

Added to different levels of education for males and females and different innate ability shocks, these sources of gender inequality in the model create distinct outcomes for men and women in terms of labor force participation, choice of formal versus informal jobs and hours dedicated to these jobs, and earnings.

\section{Benchmark Calibration}

The model is calibrated to match data from Senegal's 2011 Household Survey and aggregate data from that same year, as surveys from 2005 and 2006 do not contain individual or household-level information on earnings. ${ }^{6}$ Almost half of the parameters are calibrated jointly, in equilibrium, so that the model matches the moments from Senegal's aggregated and disaggregated characteristics in 2011. Table 2 reports the results for the parameters calibrated endogenously and Table 3 reports the exogenous parametrization values.

The model period is 18 years; thus, hand-to-mouth agents work from ages 18 to 72 and die at 72. Savers stop working at 54 and start using only their savings to consume. Because all agents die at 72 years of age, the measure of households $(\mu)$ at each period must be equal to 1/3.

Preferences. We endogenously calibrate $\xi_{l}(\varepsilon)$, which describes the family's disutility when women enter the labor market, to match the aggregate female-to-male employment ratio and to reflect the heterogeneity across income distribution of time women spend in home production. In this context, we use the number of children women have per percentile of income distribution as a proxy for this heterogeneity - in particular, the data point to poorer women having more than double the number of children as wealthier women. Using the microdata from the 2011 survey, female-to-male paid employment ratio was estimated at 60 percent and the number of children per percentile of the income distribution $n$ (ptile) is approximated by the quadratic function:

$$
n(p t i l e)=-0.0004 p t i l e^{2}-0.0028 p t i l e+6.7072 .
$$

Making the approximation assumption ptile $=\varepsilon$, we have:

$$
n(\varepsilon)=-0.0004 \varepsilon^{2}-0.0028 \varepsilon+6.7072 \text {. }
$$

Thus, the family disutility function that matches female-to-male paid employment ratio of 60 percent and takes into account the heterogeneity in households' utility costs from having a woman working was calibrated as

$$
\xi_{l}(\varepsilon)=0.0776 n(\varepsilon)
$$

The weights of the consumption goods $\left(\xi_{f o}\right.$ and $\left.\xi_{\text {inf }}\right)$ in the utility function were estimated using consumption patterns described in the household survey data, generating $\xi_{\text {inf }}=45$

\footnotetext{
${ }^{6}$ The household survey used is "Enquete de Suivi De La Pauvrete Au Senegal - ESPS II, 2011", which is the latest available comprehensive household survey containing individual and household level data on social and economic characteristics.
} 
percent and $\xi_{f o}=55$ percent. We set the discount factor $\beta$ to 0.96 annually, which is a commonly-used value in the literature. We calibrate $\theta_{1}=2$ using OECD's modified equivalence scale for the increase in household consumption when 5 children are added in the household from the initial couple of adults (with 5 being the average number of children in Senegal's households). ${ }^{7}$ Parameters $\theta$ and $\xi_{l}(\varepsilon)$ are important tools to correct for the fact that the model implies only two children per married couple.

Production. We calibrate the discrimination parameters $\phi_{f o}$ and $\phi_{\text {inf }}$ to match the female-tomale wage ratio in the formal and informal sectors (net of taxes), which are 0.74 and 0.64 , respectively. In the household survey dataset, we define a formal worker as a paid worker who declares having a formal contract with the employer and/or a paid worker who declares having affiliation, through the employer, to a social security system. Although international standards separate the definition of informal worker from a worker working in the informal sector, here we use both terms interchangeably. The endogenous calibration process gives $\phi_{f o}=0.92$ and $\phi_{\text {inf }}=0.74$. We calibrate $1-\alpha^{\text {inf }}$, the curvature of informal production function with respect to labor, to match the share of formal labor in total labor in Senegal, which is 14 percent according to 2011 household survey data. We find this curvature parameter to be 0.65 . We use 0.63 for the labor share in the Cobb-Douglas production function (meaning, $1-\alpha^{f o}=0.63$ ), which is a common value in the literature.

Initial Endowments We set 100 initial shocks/endowments, discretizing the log normal distribution of $\varepsilon$. We calibrate the variance of the shock to match Senegal's Gini coefficient of income inequality, which we calculate to be 0.63 using the household survey micro-data, thus finding $\sigma=1.22$. We also calibrate the measure of agents with access to savings at 20 percent, meaning households with 20 percent largest endowment shocks are savers and the bottom 80 percent are hand-to-mouth agents. We choose this calibration because according to the World Bank, 15 percent of Senegalese above 15 years of age had bank accounts (in our model we consider agents above 18 years of age, hence the upwards approximation). ${ }^{8}$

Human Capital Formation Function. We calibrate the parameter of the curvature of the human capital function $\alpha^{e}$ to 0.34 , which we find in the micro-data by regressing the log of education on the log of hourly wages of formal workers, controlling for other individual characteristics. ${ }^{9}$ Similarly, human capital growth is exogenously calibrated by estimating the contribution of 18 years of experience in two phases of men's and women's lives. We find $g_{2}^{f}=0.16, g_{2}^{m}=0.34, g_{3}^{f}=0.07, g_{3}^{m}=0.09$.

\footnotetext{
${ }^{7}$ Explanations and calculations available at OECD's webpage http://www.oecd.org/els/soc/OECD-NoteEquivalenceScales.pdf

${ }^{8}$ Data available at http://datatopics.worldbank.org/g20fidata/country/senegal\#

${ }^{9}$ Note that, for informal workers, earnings are elevated to the power of $\alpha^{e} \alpha^{\text {inf }}$, where $\alpha^{\text {inf }}$ is endogenously calibrated.
} 
Table 2. Calibration Results

\begin{tabular}{|c|c|c|c|c|}
\hline Parameter & Parameter value & Targeted statistic & Model & Data \\
\hline$\xi_{l}(\varepsilon)$ & $\begin{array}{l}\xi_{l}(\varepsilon) \\
=0.077 *\left(-0.0004 p t i l e^{2}\right. \\
-0.0028 p t i l e+6.7072)\end{array}$ & $\begin{array}{l}\text { Female-to-male } \\
\text { employment ratio }\end{array}$ & 0.60 & 0.60 \\
\hline$\sigma$ & 1.22 & $\begin{array}{l}\text { Gini coefficient } \\
\text { (income) }\end{array}$ & 0.63 & 0.63 \\
\hline $1-\alpha^{i n f}$ & 0.65 & $\begin{array}{l}\text { Share of formal labor } \\
\text { force }\end{array}$ & 0.21 & 0.14 \\
\hline$\phi_{f o}$ & 0.921 & $\begin{array}{l}\text { Female-to-male per } \\
\text { hour wage in the } \\
\text { formal sector }\end{array}$ & 0.74 & 0.74 \\
\hline$\phi_{\text {inf }}$ & 0.743 & $\begin{array}{l}\text { Female-to-male per } \\
\text { hour wage in the } \\
\text { informal sector }\end{array}$ & 0.64 & 0.64 \\
\hline$\tau^{v}$ & $2.63 \%$ & $\begin{array}{l}\text { Government } \\
\text { Revenues on } \\
\text { corporate taxes (as \% } \\
\text { of GDP) }\end{array}$ & 1.45 & 1.45 \\
\hline$\omega$ & 0.0467 & $\begin{array}{l}\text { Government } \\
\text { Expenditure on } \\
\text { education as \% of GDP }\end{array}$ & 6.1 & 6.1 \\
\hline$G$ & 0.085 & $\begin{array}{l}\text { Government } \\
\text { Expenditure on formal } \\
\text { goods as \% of GDP }\end{array}$ & 5.2 & 5.2 \\
\hline $\mathrm{r}^{*}$ & $6.84 \%$ per year & $\begin{array}{l}\text { Size of formal sector } \\
\text { (as \% of GDP) }\end{array}$ & 55 & 55 \\
\hline
\end{tabular}

Fiscal Policy. Effective income tax rates are calculated by applying 2011's tax rules on average income from work in each percentile of Senegal's income distribution. ${ }^{10}$ According to our calculations, the bottom 42 percent of Senegal's income distribution did not need to pay taxes in the formal sector. For percentiles $43^{\text {rd }}$ to $100^{\text {th }}$, we smooth the resulting tax rates, which gives a range of 0.01 to 0.31 effective income tax rates for these percentiles. Tax on consumption $\tau^{c}$ is set to 18 percent for Senegal, which was the statutory rates at that time. We calibrate taxes on companies' revenues $\left(\tau^{v}\right)$ to match total government's revenue collection in corporate taxes in Senegal (1.45 percent of GDP, according to the IMF), resulting in a 2.6 percent hypothetical effective tax rate on revenues. Using national accounts data, we calibrate government spending on formal goods G to be 5.2 percent of GDP. Furthermore, the parameter $\omega$ of government spending on education is calibrated to match the total government education spending of 6.1 percent of GDP, also according to national accounts data of 2011. We use the household survey to calculate the years of education of each percentile of the income distribution and for each gender, so that total education spending is the product of $\omega$ and the number of years of education of each percentile-gender group (for instance, working women

\footnotetext{
${ }^{10}$ Source: http://www.iberglobal.com/files/Senegal_deloitte.pdf
} 
from percentile 10 received on average 1.6 years of education while men from the same percentile received 2.7 years).

International interest rate. We calibrate the real interest rate in Senegal to match the relative size of the formal sector, which is estimated at 55 percent of GDP. This is done because the formal sector is the only sector that uses capital in this economy (which is a tradable formal good). We find $\mathrm{r}^{*}$ to be 6.8 percent per year.

\section{Table 3. Parameters}

\begin{tabular}{c|l}
\hline$\xi_{\text {inf }}$ & 0.45 \\
$\xi_{f o}$ & 0.55 \\
$\beta$ & 0.96 \\
Percentage of savers & 20 \\
$\alpha^{e}$ & 0.342 \\
$\alpha^{f o}$ & 0.37 \\
$g_{2}^{f}$ & 0.16 \\
$g_{2}^{m}$ & 0.34 \\
$g_{3}^{f}$ & 0.07 \\
$g_{3}^{m}$ & 0.09 \\
$\tau^{c}$ & 0.18 \\
\hline \hline
\end{tabular}

\section{Results}

We perform two experiments to quantify the importance of women's schooling and working conditions on the increase in female labor force participation and employment in Senegal from 2006 to 2011. ${ }^{11}$ The first experiment quantifies the impact of the observed improvement in years of education of the working age population on female labor force participation and on other relevant variables contained in the model, such as GDP and income inequality. The second experiment hypothetically assumes the remaining female labor force participation growth observed in the period was due to improvements in labor market discrimination parameters $\phi_{f o}$ and $\phi_{\text {inf }}$. It quantifies how much these parameters should have changed in order to boost female labor force participation by the desired amount, and analyses the behavior

\footnotetext{
${ }^{11}$ This is a simple model to solve, we first solve the household problem for all possible FLFP choices and then we maximize to find the solution that gives the highest level of utility for a given prices. We then iterate until we find the equilibrium prices that solve the market clearing conditions.
} 
of other variables under these changes. ${ }^{12}$ It is important to note that general equilibrium effects of these two shocks over female labor force participation (or employment) should be observed after decades, therefore the results presented in this section provide upper bounds of the role of education and labor market discrimination on the observed boost in female labor force participation. ${ }^{13}$ We set 2011 as our baseline year, as this is our fully calibrated year due to data availability.

\section{A. Simulating the Observed Increase in Years of Education of the Labor Force}

In this simulation, starting from the baseline year of 2011, we reduce the number of years of education of the labor force to the estimated 2006 levels, mimicking the observed changes in years of education of working age population in the 2005 and 2011 household survey data (as depicted in Figure 1e). Changes in years of education are computed for each income level and for females and males separately. Furthermore, we reduce the government spending on education according to the data, which shows 5.1 percent of GDP being spent on education in 2006 (versus 6.1 percent of GDP in 2011). We then analyze the impact on labor market outcomes for different income levels and gender (including the resulting changes on female labor force participation or employment) as well as on productivity, inequality, and growth. We present the main results in Figure 2.

The observed changes mount to increases in years of education for both men and women that reduces gender gaps in years of education. According to the model, this affects positively the human capital and wages of all workers and, at the same time, provides enough competitiveness and incentives for some women to join the labor force. Figure 3a shows that household per capita income increases for all deciles of the income distribution.

The changes in education induce some women in the $1^{\text {st }}, 2^{\text {nd }}$ and $3^{\text {rd }}$ deciles of the income distribution (with lower skills) to enter the labor force through the informal sector, most notably younger women. Younger women have a higher probability of supplying labor because their husbands' earnings are lower in the initial period of working life (as wages grow with years of experience at a rate g); thus, these younger families have a higher marginal utility to consume and hence larger gains from having wives working in the labor market. Female-tomale labor force participation would increase in the long run by 6.1 percentage points (Figure 2a), meaning 44 percent of the total percentage gains of 14 points observed in the 2006-2011 period.

The surge in levels of education also induce women from the $4^{\text {th }}$ to the $10^{\text {th }}$ decile of the income distribution to shift some of their time dedicated to work in the informal to the formal sector, mostly notably women from the $5^{\text {th }}$ and $6^{\text {th }}$ deciles, thus increasing by 7.8 percent the aggregate number of hours women work in the formal sector. Male workers from the $4^{\text {th }}$ decile up - most

\footnotetext{
12 Note that there are reasons to believe that indeed Senegal went through a period of female empowerment during the 2000s - for instance in 2010, president Abdoulaye Wade signed a gender parity law, aiming at a $50 / 50$ gender division in political representation.

13 To reduce the discrepancy between these upper bounds and reality, we use for calibration purposes the data on years of education of individuals who work instead of education of young adults only.
} 
notably from $6^{\text {th }}$ to $8^{\text {th }}$ deciles of the income distribution - who became more educated due to the education policy, also shift some of their time from the informal to the formal labor, generating an increase of 2.1 percent in the number of hours males work in the formal sector.

These changes in the labor market raises productivity of labor (measured as total product per worker) by 0.8 percent in the formal sector and by 1.3 percent in the informal sector (Figure $2 \mathrm{~d}$ ) and a marginal increase in prices of informal goods (by 0.3 percent). The increase in the informal good price and the increase in productivity in the informal sector bring more income to poorer households, as they work relatively more in the informal sector than richer households. In terms of labor earnings, women's average labor earnings grow by 7.1 percent with the policy, while men also see their wages increase (by 3.6 percent - Figure $2 b$ ). With this, the gender pay gap shrinks by 2.2 percentage points (Figure $2 \mathrm{c}$ ).

The generalized increase in education and the reduction of gender gaps in education generate gains in per capita household income for all deciles of the income distribution, notably deciles $1,2,5$, and 6 , where women either joined the labor force or men and women shifted some labor time to the formal sector (where wage discrimination is lower). In terms of measures of income inequality, the income ratio between richest ten percent and poorest ten percent would fall by 2.3 percent, and the ratio between richest 50 percent and poorest 50 percent would fall by 4.6 percent. The Gini index would decrease by one percentage point. The reason the Gini does not reduce further is that, given the very unequal income distribution, the increase in income in the last deciles, although relatively lower in percentage change terms, are large in absolute terms.

Regarding the aggregate economy, the increase in education has a positive impact on GDP of 5.7 percent. The effect is due to gains in production (increase in labor force participation) and in productivity, translating into a boost in aggregate consumption of 5.1 percent. The GDP growth generates higher government tax collection to the tune of 0.9 percent of GDP, mostly coming from surging consumer tax and income tax on wages in the formal sector. These gains could be much larger if the formal economy were larger, as it would allow the government to collect more taxes from firms and employee in the formal sector. We assume the policy cost is one percent of GDP per year, which is the difference between the observed government yearly education expenditure from 2006 to 2011 . In this case, the net government expenditure effect would be $0.1 \%$ of GDP per year in the long run. Note however, that although policy costs and resulting revenues are expressed in yearly terms, the time frame for the revenues to materialize is longer, as the education policy takes many years to translate into a higher skilled labor force.

\section{B. Simulating the Reduction in Discrimination in the Labor Market}

In this section we change gender discrimination parameters $\phi_{f o}$ and $\phi_{\text {inf }}$ so that, together with the boost in education as simulated in A, the model can explain all of the observed rise in female employment from 2006 to 2011. Since this is a hypothetical simulation and we do not wish to impose any a priori information on what happened in terms of gender discrimination in the formal and informal labor markets in Senegal at that time, we assume that both $\phi_{f o}$ and $\phi_{\text {inf }}$ improved by the same amount. We thus find that the necessary change in these parameters would need to be of 4.7 percentage points. 
In order to explain both the marginal effect of reducing gender discrimination and the total effect of a policy package that reduces discrimination and improves education, we present below the results of two exercises, namely: (i) keeping the lower 2006 education levels and increasing $\phi_{f o}$ and $\phi_{\text {inf }}$ by 4.7 percentage points to understand the marginal impact of reducing discrimination and; (ii) improving both education levels (from 2006 data to 2011 data) and gender discrimination (increasing by 4.7 percentage points) so that the model can explain all of the observed boost in female employment from 2006 to 2011.

\section{Marginal changes in reducing discrimination in the labor market}

Contrary to the education exercise, the reduction in residual discrimination does not affect positively all households, being more beneficial to deciles 2 and 6 of the income distribution and marginally detrimental to the poor (Figure $3 b$ ). The policy provides enough incentives and competitiveness for women in the $2^{\text {nd }}$ decile of the income distribution to enter the labor force, in particular in the informal labor market. The entrance of lower skilled labor (smaller $\varepsilon$ ) in the labor force reduces productivity in the informal sector by 2.1 percent but still brings down prices of informal goods by 1.2 percent. The higher consumption levels in this economy resulted by the larger labor force participation - induces more production in the formal sector, so that men from the $6^{\text {th }}$ to the $10^{\text {th }}$ decile shift some of their time spent working in the informal to the formal sector. Also, mid-to-highly skilled working women (from $6^{\text {th }}$ to $10^{\text {th }}$ deciles) have now more incentive and productivity to compete in the formal labor market, shifting some of their time to that sector. In equilibrium, the lower discrimination in the formal labor market boosts productivity in the formal sector by 1.9 percent (Figure 2d). Deciles 1 to 3, composed of households working in the informal sector, lose some purchasing power due to the reduction in prices of the products that they sell (informal goods), which explains the small loss in household per capita income in deciles 1 and 3 (Figure 3b).

In terms of labor earnings, the decrease in discrimination in the labor markets boosts women's average labor earnings by 6.4 percent, while higher competition in the labor market slightly pushes down men's wages by 0.1 percent (Figure $2 b$ ). The total female-to-male labor earnings ratio improves by 4.0 percentage points (Figure $2 \mathrm{c}$ ).

The labor market shifts in deciles 2 and 6 and in later deciles, as described above, are the main drivers of the unequal household income gains presented in Figure 3b. In terms of inequality measures, the income ratio between richest 10 percent and poorest 10 percent rises by 3.1 percent, and the ratio between the richest 50 percent and poorest 50 percent grows by 1.4 percent, meaning an increase in income inequality. The Gini index decreases marginally, by less than one percentage point given the higher income gains enjoyed by the middle class, notably deciles 5 and 6 , and by households in the second decile of the income distribution (Figure 2e).

Regarding aggregate output, the reduction in discrimination in the labor market has a positive impact on GDP of 4.0 percent (Figure $2 \mathrm{f}$ ). This rise is caused by the increase in female labor productivity (due to lower discrimination) and by demand effects (aggregate consumption increases by 3.5 percent). The expansion of GDP raises government revenues collection by 0.6 percent of GDP, due to higher receipts of labor income taxes and consumption taxes. We 
cannot estimate the cost of this policy to the Senegalese government coffers, but the cost could be low if the main drivers of lower discrimination were changes in the population's perceptions or changes in the legal framework towards more gender equality. For instance, the 2010's gender parity law, which required Senegalese political parties to ensure that at least half their candidates in local and national elections were women, could have been a culmination of gender-parity efforts around the country in the first decade of the century.

\section{Simulating both anti-discrimination and education policies at the same time}

Combining the education and the anti-discrimination policies generates GDP growth of 10 percent, a ted higher than the sum of these policies simulated separately. As expected, the package explains all 14 points increase in female-to-male employment ratio observed in the Senegalese data between 2006 and 2011. The most positively affected deciles of income distribution are the $2^{\text {nd }}$ (as females from that decile join the labor force due to both education and anti-discrimination policies) and the $6^{\text {th }}$ decile - as some men and women with higher human capital shift to the formal sector, improving their earnings (Figure 3c). Both Gini coefficient and top 50 versus bottom 50 income ratio improve. However, income gains in the $10^{\text {th }}$ decile is larger than the gains of the $1^{\text {st }}$ decile, leaving the top 10 percent to bottom 10 percent per capita income ratio larger. This negative effect could be compensated by using redistribution policies such as cash-transfers funded by the increase in government revenues, which amounts to 1.6 percent of GDP. Figures 2 and 3 below compare results of the education and the anti-discriminatory policies, separately and combined.

\section{Conclusions}

We develop a micro-founded overlapping generations model that allows us to analyze the impact of fiscal and gender-related policies on aggregate and disaggregated variables, including labor market outcomes. In this framework, women face different barriers to their development over the life-cycle, starting from early education, passing through the cost of child bearing, and later through discrimination in the labor market. We use this model to quantify the impact of reduction of gender gaps on female labor force participation and employment observed between 2006 and 2011 in Senegal.

We find that the increase in education levels and the reduction of gender gaps in education during that period could have added up to 6.1 percentage points to the female-to-male employment ratio, which corresponds to 44 percent of the growth observed. According to the model, the higher provision of education contributed to both larger economic growth and lower income inequality. Education levels not only improved for both men and women but also reduced gender gaps in education, enhancing women's competitiveness in the labor market and raising their returns from participating in the labor force.

We also find that a 4.7 percent reduction in the so-called unexplained wage gap (a reduction in discrimination in the labor market) during that period would have had the potential to boost female labor force participation by extra 7.9 percentage points in the long run, corresponding to the remaining 56 percent of the total gain of 14 percentage points in the female-to-male employment ratio in the 2006-2011 period. Despite having a large effect on employment and on GDP, the anti-discrimination policy outcomes are not well distributed across the population; 
in fact, they can be slightly detrimental to some lower income families (deciles 1 and 3 of the income distribution). However, the costs of this policy could be relatively low if, for instance, the changes are made through improvement of gender equality in the legal framework or in the perceptions of the society. The government could use the revenue gains from higher tax collections to redistribute to the poor.

We leave for future research the simulations on other policies targeting gender gaps that can be performed with this framework, such as: changes in taxes and transfers, improvements in health outcomes for women, reduction in fertility rates, and ameliorations in infrastructure that could benefit women and men differently. 
Figure 2. Results of the Education and Anti-Discriminatory Policies

(a)

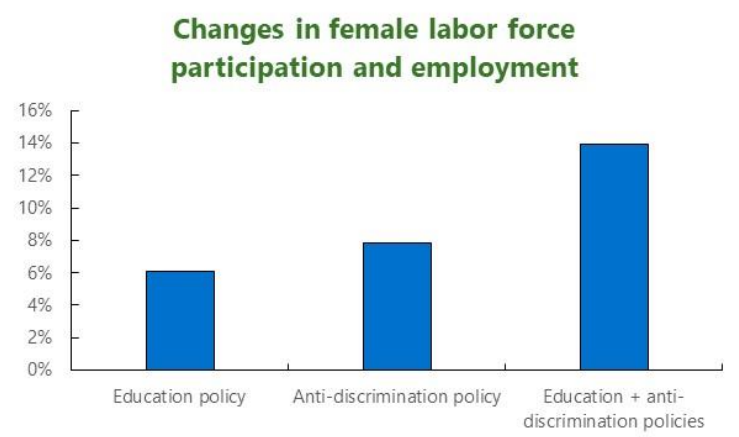

(c)

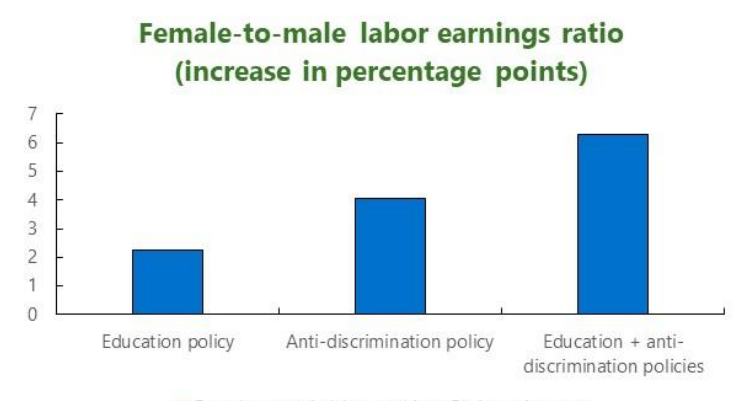

- Female-to-male labor earnings Ratio pp increase

(e)

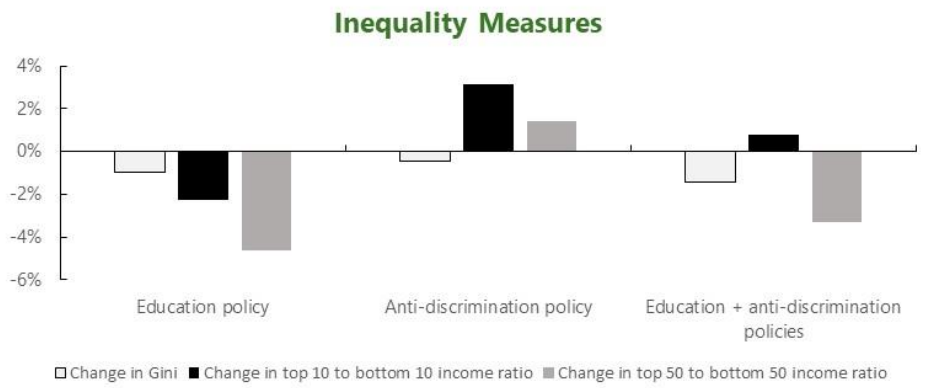

(b)

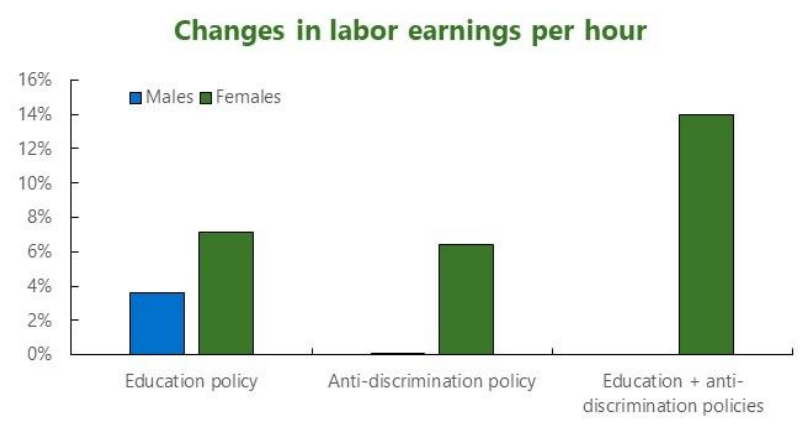

(d)

Changes in productivity

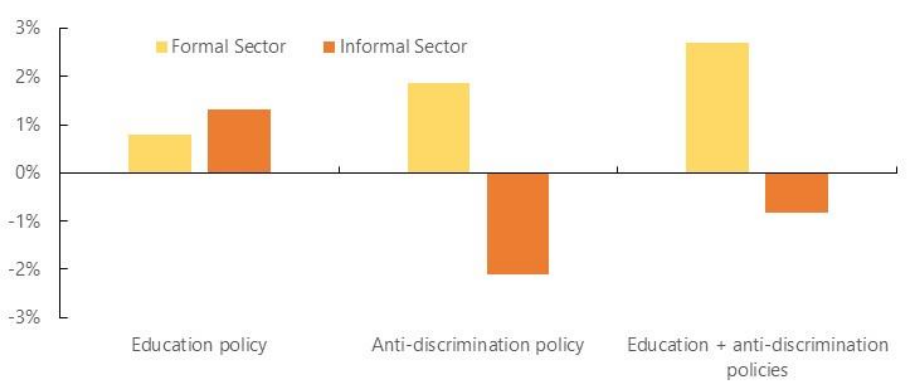

(f)

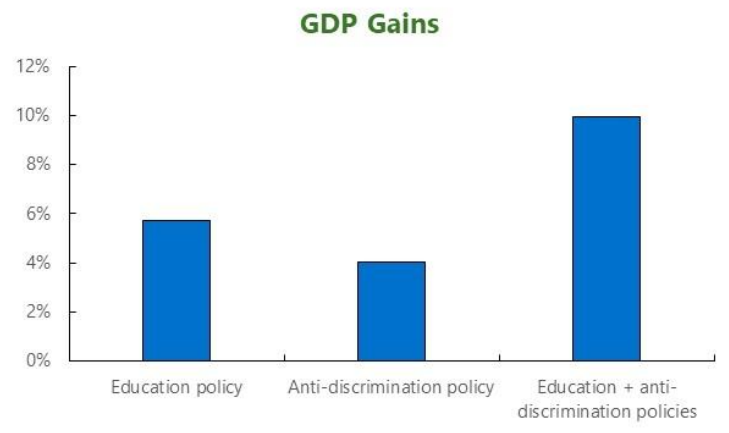


Figure 3. Changes in Households' Per Capita Income, by Decile of Income Distribution

(a)

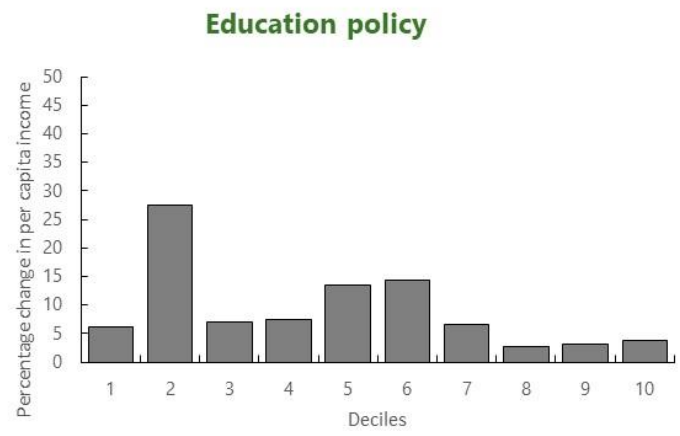

(b)

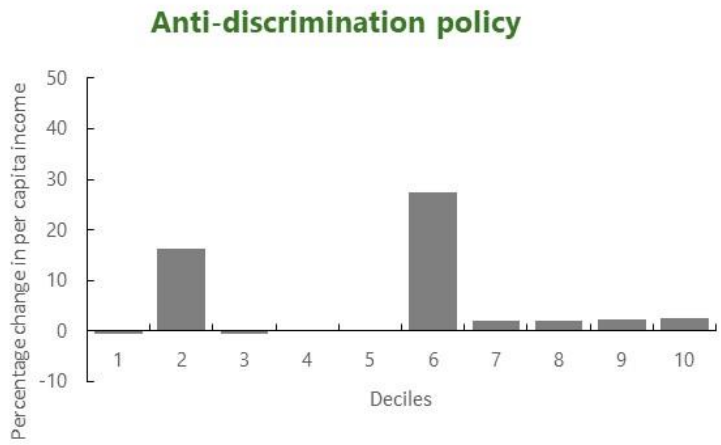

(c)

Education + anti-discrimination policies

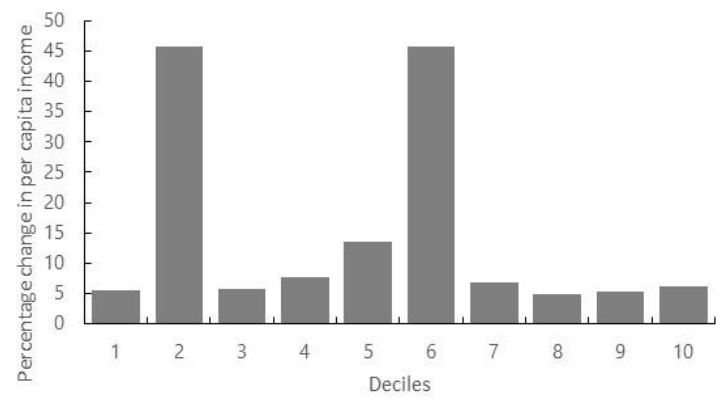




\section{REFERENCES}

Albanesi, S. and Claudia O., 2009. "Home Production, Market Production and the Gender Wage Gap: Incentives And Expectations." Review of Economic dynamics 12.1 pp: 80-107.

Azmat, Ghazala, 2015. "Gender Gaps in the UK Labour Market: Jobs, Pay and Family-Friendly Policies." London School of Economics and Political Science: Centre for Economic Performance.

Becker, Gary S., 1985. "Human Capital, Effort, and the Sexual Division of Labor." Journal of labor economics Vol. 3, No. 1, Part 2 pp: S33-S58.

Blau, F. D., and Jed D., 2007. "New Evidence on Gender Differences in Promotion Rates: An Empirical Analysis of a Sample Of New Hires." Industrial Relations: A Journal of Economy and Society Vol. 46.3 pp: 511-550.

Bowen, W. G., and T. Aldrich Finegan, 1966. "Educational Attainment and Labor Force Participation." The American Economic Review Vol. 56, No. 1/2 pp: 567-582.

Brussevich, M., Era D., Christine K., Pooja Ka., Salma K., and Kalpana K., 2018. “Gender, Technology, and the Future of Work". International Monetary Fund, Staff Discussion Note $18 / 07$.

Budlender, D., and Guy H., 2003. "Engendering Budgets: A Practitioners' Guide to Understanding and Implementing Gender-Responsive Budgets". London: Commonwealth Secretariat.

Chade, H., and Gustavo V., 2002. "Taxes and Marriage: A Two-Sided Search Analysis." International Economic Review Vol. 43.3 pp: 955-985.

Christiansen, L., Huidan L., Joana P., Petia T., and Rima T., 2016. "Individual Choice or Policies? Drivers of Female Employment in Europe". International Monetary Fund, Working Paper 16/49, Washington, DC.

Cobb-Clark, D.A., 2001. "Getting ahead: the determinants of and payoffs to internal promotion for young US men and women”. In Worker wellbeing in a changing labor market (pp. 339372). Emerald Group Publishing Limited.

Dabla-Norris, Ms Era, Ms Kalpana Kochhar, Mrs Nujin Suphaphiphat, Mr Frantisek Ricka, and Evridiki Tsounta, 2015. "Causes and consequences of income inequality: A global perspective". International Monetary Fund. Washington, DC.

Das, Sonali, Sonali Jain-Chandra, Kalpana Kochhar, and Naresh Kumar, 2015. "Women Workers in India: Why so Few Among so Many?” International Monetary Fund, Working Paper 15/55, Washington, DC. 
Eckstein, Zvi, and Osnat Lifshitz, 2011. "Dynamic Female Labor Supply". Econometrica 79, No. 6, pp: 1675-1726.

Elson, Diane, 2003. "Gender Mainstreaming and Gender Budgeting". Gender Equality and Europe's Future. London: Women's Budget Group.

Ganguli, Ina, Ricardo Hausmann, and Martina Viarengo, 2014. "Closing the Gender Gap in Education: What is the State of Gaps in Labour Force Participation for Women, Wives and Mothers?" International Labour Review 153, No. 2, pp: 173-207.

Grown, Caren, and Imraan Valodia, 2010, "Taxation and Gender Equity: A comparative analysis of direct and indirect taxes in developing and developed countries". IDRC. Vol. 58.

Guner, Nezih, Remzi Kaygusuz, and Gustavo Ventura., 2011. "Taxation and household labour supply". The Review of economic studies 79, No. 3, pp: 1113-1149.

Jacobsen, J.P., 1998. “The economics of gender”. Vol. 631207279, Malden, MA: Blackwell.

Kalb, Guyonne. 2018. "Paid Parental Leave and Female Labour Supply: A Review". Economic Record 94, No. 304 pp: 80-100.

Kaygusuz, Remzi, 2018. "Taxes and Female Labor Supply". Review of Economic Dynamics No. 13.4 pp: 725-741.

Kilic, Talip, Edward Whitney, and Paul Winters, 2014. "Decentralized Beneficiary Targeting in Large-Scale Development Programmes: Insights from The Malawi Farm Input Subsidy Programme". Journal of African Economies 24.1 pp: 26-56.

Kolovich, L., 2018. "Fiscal Policies and Gender Equality” (Washington, DC: International Monetary Fund).

LaLumia, Sara, 2017. "Tax Policies to Encourage Women's Labor Force Participation". Driving Growth through Women's Economic Participation. P. 71.

IMF, 2016. "Guatemala: Selected Issues". IMF Country Report N.16/282, Washington, DC.

IMF, 2017a. "Austria: 2016 Article IV Consultation”. IMF Country Report N.17/26, Washington, DC.

IMF, 2017b. “Arab Republic of Egypt: 2017 Article IV Consultation”. IMF Country Report N.17/17.

IMF, 2017c. "India: Selected Issues". IMF Country Report N.17/55, Washington, DC.

IMF, 2017d. "Rwanda: Selected Issues". IMF Country Report N.17/214, Washington, DC. 
IMF, 2017e. “Argentina: Selected Issues". IMF Country Report N.17/410, Washington, DC.

Jain-Chandra, Sonali, Kalpana Kochhar, Monique Newiak, Yang Yang, and Edda Zoli, 2018. "Gender Equality: Which Policies Have the Biggest Bang for The Buck?", International Monetary Fund, Working Paper 18/105, Washington, DC.

Marzo, F. and Atuesta, B. "Breaking Out of the Productivity Trap: How Gender Inequalities Lock Senegal's Women Into Lifetimes of Lower Income". The World Bank. (forthcoming).

Mincer, Jacob, and Solomon Polachek., 1974. "Family Investments In Human Capital: Earnings of Women". Journal of political Economy 82, no. 2, Part 2 pp: S76-S108.

Ostry, Mr Jonathan David, Mr Andrew Berg, and Mr Charalambos G. Tsangarides, 2014. "Redistribution, inequality, and growth". International Monetary Fund.

Peralta-Alva, Adrian, Xuan Song Tam, Xin Tang, and Marina Mendes Tavares., 2018. "The Welfare Implications of Fiscal Consolidations in Low Income Countries". International Monetary Fund, Working Paper 18/146, Washington, DC.

Schultz, T. Paul., 1990. "Women's Changing Participation in the Labor Force: A World Perspective." Economic Development and Cultural Change 38, No. 3 pp: 457-488.

Steinberg, C., and M. Nakane., 2012. “Can Women Save Japan?” International Monetary Fund, Working Paper 12/48, Washington, DC.

Stotsky, Janet, 2006. “Gender Budgeting”. International Monetary Fund, Working Paper 06/232, Washington, DC.

Stotsky, Janet, 2016. "Gender Budgeting: Fiscal Context and Current Outcomes." International Monetary Fund, Working Paper 16/149, Washington, DC.

Thévenon, Olivier., 2013. "Drivers of Female Labour Force Participation in the OECD". OECD Social, Employment and Migration Working Papers, No. 145, OECD

World Bank, 2006. "Senegal - Quality Education for All Program".

World Bank, 2012a. "Senegal - Second Quality Education for All Project".

World Bank, 2012b. "World Development Report 2012: Gender Equality and Development".

World Bank, 2018. "Women Business and the Law". 